\title{
PERCHANCE TO BLEAM
}

\section{Sleep no more ...}

\section{BY RONALD D. FERGUSON}

$\mathrm{T}$ hree days since the radio burst and Martin hadn't slept. Normally, Martin worked nights monitoring data from the radio telescope. When alone, he broke the monotony of the scrolling star signatures by snacking; but since insomnia had struck, he had become increasingly restless. By the second sleepless day, he had night-walked among the antennas and wished the friendly stars would soothe him. But when he went home the next morning, his eyes still refused to close.

Homespun remedies were ineffective. Martin gagged at the thought of another glass of warm milk. Encapsulated tryptophan made him listless, not sleepy. Likewise, the exercise theory gave him sore muscles but not sleep. Despite his efforts, Martin never got drowsy.

Over a weekend brunch, he shared his sleep problems with Julia. Last year, they had unsuccessfully worked on a romance, but that relationship had degenerated into a close friendship.

Julia sympathized. After three glasses of wine, she reached across the table and touched his hand.

"I remember what puts you to sleep."

The experience was memorable, certainly better than warm milk, but Martin finished invigorated rather than enervated.

When darkness finally punctuated the rhythm of Julia's breathing, Martin wrestled his thoughts and waited for sleep. Hours later, sleep hadn't come. He illuminated his watch: 8:47 p.m., time to get up. He caressed Julia's shoulder, eased himself from the bed and got dressed.

In the hall, he scribbled a thank-you-calltomorrow note and stuck it to the mirror. Outside, the cool night air refreshed him, and he walked the streets until dawn.

\section{"How do you feel, Martin?" \\ "Not bad, Dr Hendley. Irritable. Mildly depressed." \\ "No aches or pains?" \\ "My health is fine. I saw my doctor before I came to you. He couldn't do much for me, except pronounce I was in good health." \\ "I'm surprised. No pharmaceuticals?" \\ "I tried a sleep clinic two days ago, but it didn't work. They thought I was sleeping with my eyes open, but} I wasn't. Drugs rendered me unconscious twice, but never to REM sleep."
NATURE.COM
Follow Futures on

Facebook at:

go.nature.com/mtoodm

\author{
"How long now?" \\ "Eight days. I haven’t slept in eight days."
}

"That's the fifth massive burst in the past two weeks. Did you read the transmission? Martin? Hey, Martin, are you awake?"

Of course he was awake. He was always awake, working double shifts to fill his time - what the heck!

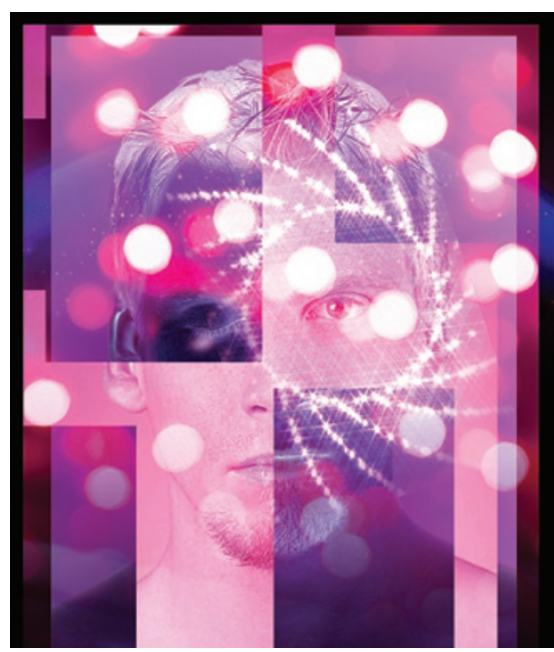

As he watched the computer screen, invisible nanos assembled into robot roaches and marched intricate formations backlit by the LCDs. First, they spelled 'Hello', then they lined up and presented their antennae for inspection. The antics entranced him. Martin pointed to the screen and giggled.

Strong hands pulled at his arms and helped him to stand. Martin appreciated their effort, but he resisted, straining towards the screen because the roaches had more to tell him.

"What's wrong with him?" A distant voice, maybe it was God, asked. "Is he on drugs?"

"The guy hasn't slept in weeks, not since we attended the SETI conference. You know, the night of the first big transmission burst?"

"Okay. Call EMS. Get him to the hospital."

"Why must people sleep, Dr Hendley?" Martin swallowed two aspirins.

"I'm more interested in why you can't sleep. Fifteen days now."

"Doesn't worry me anymore."

"Maybe not worrying is another hallucination, Martin. Stay focused."

"But why should I sleep? Give me one good reason. With that, I'm sure I could sleep."

"Okay." Dr Hendley sighed. "Prolonged sleep deprivation harms your health."
"That's not my question."

"I understand, but the rest is only an opinion. Sleep allows our bodies to recover, but more, sleep allows the mind to assimilate its experiences. I believe dreams are the mind's attempt to reconcile the day's experiences with what it already knows."

"So dreams install a software upgrade, and waking is the required system reboot. We sleep to dream."

"Nice analogy. I hadn't thought of that. I'm not big with computers."

Martin rocked his chair. The rhythm soothed him. "What if it's too much?" he whispered.

"What if what's too much?"

"The day's experiences. What if the information is so massive, so at odds with what the mind already knows, that each installation attempt results in failure?"

"When that happens with my computer, the tech says I need a hardware upgrade. But to answer your question, Martin, I don't know. Do you think that's what happened to you?"

"Maybe mental hardware is different." Martin closed his eyes. "Maybe eventually, the mind upgrades itself. Too late for me. I'm exhausted. Death almost looks good."

"Courage, Martin. I've called sleep specialists in New York and Los Angeles. They are fascinated by your ... Martin? Are you okay?"

The waking hallucination of dream-filled sleep became a sleeping dream displaying distorted reality. Roaches waved antennae at him. Data flashed across his screen. Recursive memory filled, but for this iteration, reallocated storage before it could overflow. Reboot. Reload the dream to finish the installation.

The bleam opened in multidimensional high definition with vivid colours and surround sound. Was the overture a celestial choir or a galactic orchestra? The unfiltered vibrations assaulted Martin with rumbling lows and tingling highs that soared past human experience. He absorbed sounds beyond the limits of his ears. His mind juggled colours below the infrared and above the ultraviolet. The dream issued smell, taste and feel. The view expanded to a four-dimensional kaleidoscope of scenes and senses.

Finally awake to the mystery of the bleam, Martin smiled in his sleep. What an introduction, what a spectacular greeting from the radio-telescope data.

... And a big hello right back at you. .
Ronald D. Ferguson lives with his wife and five feral cats in the Texas Hill Country. 